\title{
Designing of Educational Game Tools for Early Childhood Development Based on Islamic Values
}

\author{
Miratul Hayati \\ Syarif Hidayatullah State Islamic University Jakarta, Jl. Ir. H. Djuanda 95, Ciputat, Indonesia \\ Corresponding e-mail: miratul.hayati@uinjkt.ac.id
}

\begin{abstract}
Using of educational game tools considers child development to stimulate children personal, intellectual growth, language ability, cognitive, social ability, emotional, motor skills, physical coordination, art and religious morals. Educational game tools is using by concrete objects in the learning process. This is consistent with the Piaget's theory that early childhood is at a concrete operational stage. Appropriately planned stimulation encourages children to explore and experiment at their own levels where they can use object to construct relationship and understanding. This study aims to develop early childhood educational game tools based on Islamic values contained in the Qur'an. The method used in this research is to develop the learning media and game tools for early childhood based on Islamic values. By exploring contextual themes with learning such as prayers, zakat, fasting, stories, sciences and moralities. The position of learning media based on Islamic values on previous research is to embed the characteristics of divinity, safety, and welfare in learning. During this time the child has not been introduced to the divine approach. That is to say and know the man, animals, sky, earth and the universe are God's creation. This research will make it easier for teachers to create fun learning and to immerse children while learning through play which is guided by the Islamic values which is peace for world (rahmatan lil alamin).
\end{abstract}

Keywords: educational game tools, early childhood development, islamic values

\section{INTRODUCTION}

Children explore the world though playing. They learn from the environment. Furthermore, play is a mechanism whereby children learn how they explore the world, practice new skills, and internalize new ideas (Paley 2004). Through this ongoing and evolving process, the initial skills in building new experiences are integrated with the previous ones.

In this context, game tools can support children development are needed. Good toys are not necessarily expensive. Essentially, the best toys are chosen according to the child's age, development, and interests. Appropriate play for children can be produced by children through from the helping of parents and teachers. It's can be produced from utilization of goods at home such as cloth, bottles, cardboard boxes, yarns, cooking pots, and others are limited.
Furthemore, the function of game tools for children is to pay attention to various aspects. The culture and community of children are an inseparable part. Children living in areas should be invited closer to the sea such as making ships, making buildings from sand, making crafts from shells and so forth. So also with children living in the city. Children need to be introduced with highways, mass vehicles, buildings and so on.

The appropriate game tools with time and resources, can be more personal way to build relationships between teachers and children. Teacher can direct child to create an interesting game tool. Game tools are effective, safe and appropriate to their age, abilities, and interests. And the selection of the right game is expected to stimulate language, fine motor, gross motor, social-emotional, and cognitive development, moral development, and religious values. 


\subsection{Educational Game Tools}

Using game tools in learning very helpful for children. Children able to develop their potential and interests and also develop meaningful games. Baltra argues that "Play is a very old and widespread form of learning and children do their learning mainly through game or game activities, so it is not surprising that most educational activities in preschool years try to simulate the game" (Baltra 1990). Although the game may "end up in school" (Baltra 1990).

In general, the importance of game-based learning for early childhood needs to look at fun games and learning that are associated with early language learning (Crookall 2007). In addition, learning-based games can offer an exciting and safe environment where children can experiment and make mistakes (Ortega 1997). According to Gaudart (1999), both simulations and games allow children not only to practice the forms they have learned, but also to experiment with new structures.

In this case, athreatening learning environment with the game gives the child opportunity to practice and provides immediate and simultaneous feedback. Feedback is important for children to create continuity, improving and sustaining motivation and in supporting learning where teachers are absent or close to children. The combination of game elements and exercises can therefore help open the space for playing games in elementary schools around the world where the focus is often on learning basic skills, such as engaging and child-centered learning. The game tools in subsequent learning provide wider space for the child to explore the environment and the wider world. Children are not only limited to the tools they have but also enhance the creativity, and innovation for life.

\subsection{Early Childhood Development}

Early childhood is an extraordinary time opportunity for the growth and development in all aspect of child development, such as: physical, motor, language, emotional and cognitive ability. An important age (critical period) in the development and growth of children is a basis of development and growth for the next. And also the process of growth and development in various situations are developing in the range of development of human life. Santrock argues that childhood is a highly eventful and unique period of life of the child's growth in this phase very vital to the next life. (Santrock, 20012) Early childhood is a very basic stage for child development as laying the foundation for someone in adulthood.
Early childhood is the golden age of brain development. One of the results about this study mentions, the capacity of children's intelligence at the age of 4 years has reached $50 \%$, this capacity will increase to $80 \%$ at the age of 8 years. It shows the importance of providing the right stimulus for the child. This stage is as preparation stage for organizing concrete operations. Child's thinking based more on concrete experience than logical thinking, so that if they look an object, they will look different, they will say it is different. Also child is still at the preoperational stage has not understood the concept of conservation (conservation), the eternal length, material conservation, breadth, etc. In addition, the characteristics of children at this stage have not understood and cannot think of two or more aspects simultaneously.

In this case development of game tools in learning is very appropriate with Early Childhood learning that emphasizes concrete learning. (Sensory motor, pre-operational and concrete operations). This is according to Piaget, about the stage of early childhood cognitive development. The educational game tools include to use of audio media, visual media, audio visual media, specifically also the manufacture of three-dimensional media such as diorama, busy book, clay, play dough, flannel apron, utilization of used goods, and so on.

\subsection{Islamic Values}

Islamic values are the values contained in the Qur'an. Islamic values in the Qur'an are spread in letters and verses of the Qur'an. Every value is contained in the Qur'an has a meaningful lesson in fostering faith, humanity and morality. Islamic values are principle that needs to be instilled since early childhood. The cultivation of Islamic values since early childhood will result in children who have moderate and characteristic insights.

In the Curriculum 2013 Early Childhood Education teachers are directed to using thematic learning. Thematic learning is seen accordance with the pattern of the brain work because it discusses a theme from various concepts and aspects of development. In determining the theme of learning can align with the child's interests, environmental situation and condition, and teacher's readiness to manage the activities.

The determination of the theme is not just easy to apply, but it is necessary to pay attention to some principles so that the lesson is more interesting and profound. Theme extension depends on the teacher's ability to master theme. In determining the theme must begin with the identification of learning objectives to be achieved. 
Developing the theme of Islamic values is very possible to observe many themes in the Qur'an, It can be explored for early childhood learning. Game tools in learning developed with the theme of Islamic Values in the Qur'an became very rich in values. Islamic, moral, religious, historical, motor, cognitive, and other sub-themes, even sub-themes developed by the teacher.

\subsection{Educational Game Tools based on Islamic Values}

Educational game is a tool used to facilitate teachers in conveying learning. Conversely, children will also dissolve in learning using the media. The media will pay attention to the goals to be generated in learning. In addition, learning will see content and context. The development of educational game tools develops Islamic Values content tailored to the context of early childhood learning. The Islamic Values content development is derived from verses in the Qur'an thematically then integrated with learning objectives. The educational game tools learning objectives are determined first and then the verses related to that purpose are explored into themes and sub themes.

Shape media design in accordance with children development and what they need. Educational game tools are developed by taking sub themes of the themes contained in the Qur'an. Products that have been developed were busy book, diorama, and planel clemek. Each product is developed with themes taken in Qur'anic values. Through this product the child can develop every aspect of its development.

\section{METHODS}

The purpose of this research is to:

1. Development of themes that serve as guidance in draft educational game tools based on the development of Islamic values theme.
2. Knowing the making of educational game tools based on Islamic Values in early childhood learning.

3. Practice to make of educational game tools for early childhood development.

Steps in making educational game tools based on thematic Islamic values as follows

1. Identify Instructional and objective goals of educational game tools appropriate to the Early Childhood

2. Observe Islamic values in the Qur'an in accordance with the general and specific objectives that have been established

3. Describe the Islamic values in themes and sub themes of learning.

4. Design games with developed sub themes

5. Creat and educational game tool.

Figure I. Design of Educational Game Tools

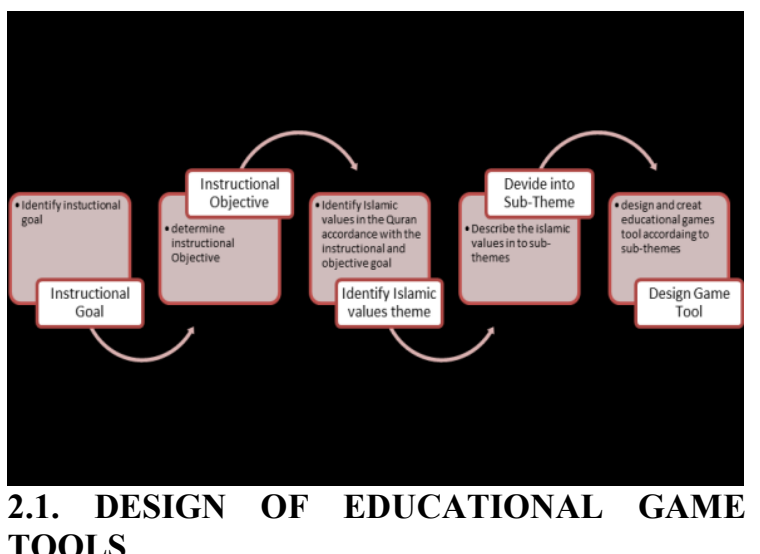

\section{TOOLS}

In this case the authors will develop game tools in Islamic Values-based learning in the following table formulated from the Qur'an, as follows in table.1: 
Table.1: Development of Educational Games Tools based on Islamic Values

\begin{tabular}{|c|c|c|c|c|}
\hline $\begin{array}{l}\text { Instructional } \\
\text { Goal }\end{array}$ & Instructional Objective & $\begin{array}{l}\text { Islamic } \quad \text { Values } \\
\text { Themes }\end{array}$ & Sub-Themes & Game Tools \\
\hline $\begin{array}{l}\text { Tauhid } \\
\text { Unity of } \\
\text { God }\end{array}$ & $\begin{array}{l}\text { - To recognize the } \\
\text { creator } \\
\text { to recognize the } \\
\text { creating of creator }\end{array}$ & $\begin{array}{l}\text { Al-Ikhlas: 1-5, Ar- } \\
\text { Ruum: } 30 .\end{array}$ & $\begin{array}{ll}- & \text { Allah } \\
- & \text { Allah's creator } \\
- & \text { Name of Allah }\end{array}$ & Busy Book \\
\hline $\begin{array}{l}\text { Prophet and } \\
\text { Messenger }\end{array}$ & $\begin{array}{l}\text { To recognize } \\
\text { prophet and } \\
\text { messenger } \\
\text { - To provide an } \\
\text { example from the } \\
\text { prophet and } \\
\text { messenger. }\end{array}$ & $\begin{array}{l}\text { Al-Anbiya: 25, } \\
\text { 107, Al-Ahzab 45- } \\
\text { 46, Al-Fath } 89 .\end{array}$ & $\begin{array}{ll}\text { - } & \text { Prophet Nuh and His Big Ship } \\
\text { - } & \text { Prophet Yunus and Shark } \\
\text { - } & \text { Prophet Ibrahim }\end{array}$ & $\begin{array}{ll}- & \text { Diorama } \\
- & \text { Apron Flanel }\end{array}$ \\
\hline $\begin{array}{l}\text { Five } \\
\text { Principle }\end{array}$ & $\begin{array}{l}\text { - To recognize five } \\
\text { principles }\end{array}$ & $\begin{array}{l}\text { Al-Ankabut: } 45, \\
\text { Al-Baqarah } 183, \\
\text { At-Taubah: } 60, \text { Al- } \\
\text { baqarah: } 168\end{array}$ & $\begin{array}{ll}- & \text { Syahadat } \\
- & \text { Prayer } \\
- & \text { Fasting } \\
- & \text { Zakat } \\
- & \text { Hajj }\end{array}$ & Busy Book \\
\hline Sciences & $\begin{array}{l}\text { - } \quad \begin{array}{l}\text { To build critical } \\
\text { thinking }\end{array}\end{array}$ & $\begin{array}{l}\text { Al-Anbiya: } 30, \mathrm{Al}- \\
\text { Mulk: } 3 \text {, An-Nur: } \\
\text { 43, Yasin: } 38, \\
\text { Zukhruf: } 11,\end{array}$ & $\begin{array}{ll}- & \text { Day and Night } \\
- & \text { What in the sky } \\
\text { - } & \text { Taste }\end{array}$ & $\begin{array}{ll}\text { - } & \text { Finger Painting } \\
\text { - } & \text { Apron Flanel }\end{array}$ \\
\hline Social & $\begin{array}{l}\text { - } \quad \begin{array}{l}\text { To build social } \\
\text { pious values }\end{array}\end{array}$ & $\begin{array}{l}\text { Al-Hujurat: 11-13. } \\
\text { An-Nisa: 86, Al- } \\
\text { Baqaah: 275, Ath- } \\
\text { Thalaq: } 6 \text {, }\end{array}$ & $\begin{array}{ll}- & \text { Trade } \\
- & \text { Help each other } \\
- & \text { Borrow and Lend }\end{array}$ & $\begin{array}{ll}\text { - } & \text { Market Creative } \\
\text { - } & \text { Bank simulation }\end{array}$ \\
\hline Morality & $\begin{array}{l}\text { - } \begin{array}{l}\text { To build moral } \\
\text { values }\end{array}\end{array}$ & 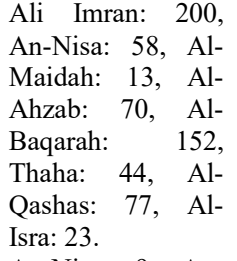 & $\begin{array}{ll}- & \text { Honest and Integrity } \\
- & \text { Patient } \\
- & \text { Good Speak } \\
- & \text { Birrul Walidain }\end{array}$ & $\begin{array}{ll}- & \text { Big Book } \\
- & \text { Finger Doll } \\
- & \end{array}$ \\
\hline $\begin{array}{l}\text { Pshysic } \\
\text { Motoric }\end{array}$ & 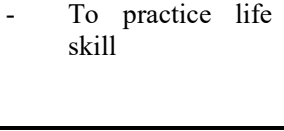 & $\begin{array}{l}\text { An-Nisa: 9, An- } \\
\text { Nahl: 80, Bani } \\
\text { Israil: } 84, \text { Al-Lail: } \\
\text { 4, Al-Isra: } 23\end{array}$ & $\begin{array}{ll}\text { - } & \text { Language Skill } \\
- & \text { Economic } \\
- & \text { - War Skill. }\end{array}$ & $\begin{array}{l}\text { Flash Card } \\
\text { - }\end{array}$ \\
\hline
\end{tabular}

\section{RESULTS AND DISCUSSION}

The development of educational game tools based on thematic Islamic values makes learning varied and broad. This allows the child to play constructively in the activities performed. Children will build they own knowledge guided by the teacher. Educational media based on educational game tools based on thematic themes of Islamic values leads to contextual learning. Through the contextualization of learning, children will discover new things close to their environment. It's developed according to the needs of the child. Children will play with their own will without coercion in running the learning. Media is packed with interesting and simple can be made by the child and his friends with the teacher's helping. This is in accordance with the principles of theme development, simplicity, attractiveness, closeness and incidental. Some of the media that are the result of excavating the themes of the Qur'an are as follows in figure 1-5
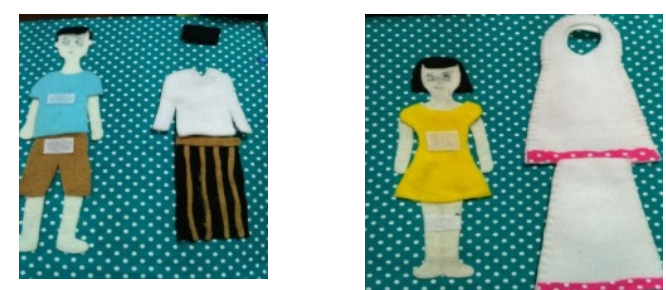

Figure 2. Educational Game Tools (Busy Book)

- Instructional Goal : Worship

- Objective Goal : Recognize prayer movement

- Educational Game Tools : Busy Book 


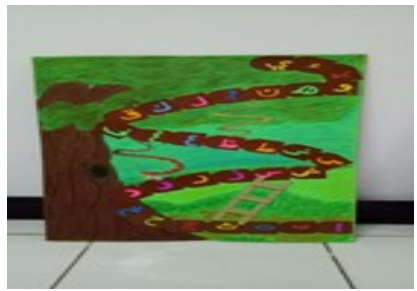

Figure 3. Hijaiyyah Alphabet Game Tools

- Instructional Goal : Love Al-Qur'an

- Objective Goal : To Recognize hijaiyyah alphabet

- Educational game tools: Hijaiyyah snakes and ladders, hijaiiyah from bottle cups

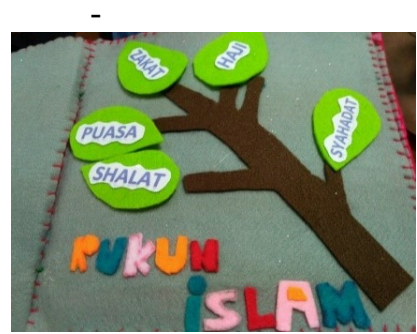

Figure. 4. Five Principles Game Tools

- Instructional Goal : Five Principle

- Objective Goal : To Recognize about five principle in islam, such as, syahadat, pray, zakat, fasting, and hajj.

- Educational game tools : Busy book and Flanel Apron.

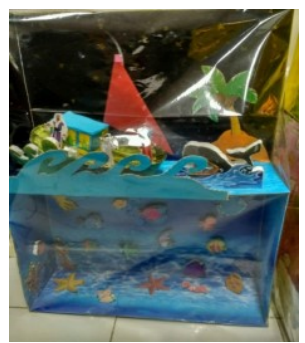

Figure 5. Diorama Game Tools

- Instructional Goal : Prophet and Massenger

- Objective Goal : To Recognize about prophet and messanger of Allah

- Educational game tools: bottle cap shark and Diorama of Prophet Yunus.

\section{CONCLUSIONS}

Early childhood is an extraordinary time opportunity for the growth and development of all aspects of child development, physical, motor, language, emotional and cognitive social. Early childhood is a very important age (critical period) in the development and growth of children on the basis of development, growth of the next age.

The development of educational game tools develops Islamic Values content to the context of early childhood learning. Islamic values content development is derived from verses in the Qur'an thematically then integrated with learning objectives. The educational game tools learning objectives are determined first and then the verses related to that purpose are explored into themes and sub themes. The development of educational game tools based on thematic Islamic values makes learning varied and broad. Educational media based on educational game tools based on thematic themes of Islamic values leads to contextual learning. The child will build his own knowledge guided by the teacher.

\section{REFERENCES}

Paley, V. (2004). A Child's Work. Chicago. IL: University of Chicago Press.

Baltra, A, (1990). Language Learning Through Computer Adventure Games, Simulation \& Gaming, 21(4).

Crookall, D. (2007). Editorial. Second Language Acquisition and Simulation, Simulation and Gaming, $38(1)$.

Gaudart, H. (1999). Games as Teaching Tools for Teaching English to Speakers of Other Languages. Simulation \& Gaming, 30(3).

Ortega, L. (1997). Processes and Outcomes in Networked Classroom Interaction: Defining the Research Agenda for L2 Computer-Assisted Classroom Discussion. Language Learning \& Technolog, 1(1).

Santrock, W. J. (2002), Life Span DevelopmentPerkembangan Masa Hidup. Jakarta: Erlangga.

Piaget, J. (1999). The Growth of Logical Thingking from Childhood To Adolescence. New York: Routledge. 